\title{
16 Institutional entrepreneurship: a literature review and analysis of the maturing consulting field Michael Smets and Markus Reihlen
}

\section{INTRODUCTION}

Professional service firms (PSFs) such as management consultancies, investment banks, and accounting and law firms have gained positions of strong economic and social influence in today's Western economies. The largest PSFs rival multinational corporations in turnover and employment, and many have extended their services beyond the business, politics, and nonprofit sectors (Empson, 2007b; Greenwood, Suddaby, \& McDougald, 2006). Management consultants have established themselves as "the world's newest profession" (McKenna, 2006) and "market protagonists" (Faust, 2002b: 45) in knowledge economies; elite law firms act as "sanctifiers" of international business transactions whose influence in many instances supplants, rather than supplements, the role of the state (Flood, 2007), and investment banks are claiming to be doing no less than "God's work" (Arlidge, 2009).

This success is to some extent a product of economic trends towards increasing knowledge intensity, servitization, globalization, and rapid innovation-however, by no means exclusively. A considerable part of PSF success is due to professionals' rhetorical and political skills actively to influence the institutional environment in which they operate. For instance, investment banks have shaped the "rules of the game" by embedding former regulators in their ranks or placing loyal employees in prominent political positions who then reinforced the myth of the inevitable "innovation cycle" and legitimized the deregulation of financial markets (Davis, 2009; Economist, 2007). Similarly, research on management fads and fashions has repeatedly recognized how management consultants strategically shape management discourse in a way that establishes their own products and innovations as sources of commercial success (Abrahamson, 1991; Benders \& van Veen, 2001; Berglund \& Werr, 2000; Kieser, 1997; Suddaby \& Greenwood, 2001).

Specifically with regard to management consulting, however, these studies have focused on the isomorphic pressures that consultants' efforts exert on their clients' industries. With few exceptions (e.g. Fincham \& Clark, 2002; Lounsbury, 2002, 2007; Montgomery \& Oliver, 2007), we know little about how emerging professions, such as management consulting, professionalize and establish their services as a taken-forgranted element of social life. This is surprising given that professionals have long been recognized as "institutional agents" (DiMaggio \& Powell, 1983; Scott, 2008) (see Chapter 17) and professionalization projects have been closely associated with institutionalization (DiMaggio, 1991).

Therefore, in this chapter we take a closer look at a specific type of entrepreneurship in PSFs; drawing on the concept of "institutional entrepreneurship" (DiMaggio, 1988; Garud, Hardy, \& Maguire, 2007; Hardy \& Maguire, 2008) we describe some generic 
strategies by which proto-professions can enhance their "institutional capital" (Oliver, 1997), that is, their capacity to extract institutionally contingent resources such as legitimacy, reputation, or client relationships from their environment. In the next section we introduce the theoretical origin and core argument of the concept of institutional entrepreneurship. We then review the literature on institutional entrepreneurship, distinguishing two phases of theory development that are associated with a varying degree of empirical attention to institutional entrepreneurship in PSFs. In the subsequent section, we present some of our own work on institutional entrepreneurship in the maturing management consulting field. The chapter closes with a reflection and discussion of implications for future research.

\section{INSTITUTIONAL ENTREPRENEURSHIP: THEORETICAL ORIGIN AND CORE ARGUMENT}

Interested in the similarity and stability of organizational structures, institutionalists initially focused on explaining convergent change in response to isomorphic pressures within organizational fields (e.g. DiMaggio \& Powell, 1983; Meyer \& Rowan, 1977; Scott, 1987; Tolbert \& Zucker, 1983; Zucker, 1977, 1983). Their over-emphasis on the social environment imposing upon - rather than also emerging from - human interaction, however, produced increasing dissatisfaction with their inability to conceptualize divergent change (e.g. Barley \& Tolbert, 1997; DiMaggio \& Powell, 1991; Greenwood \& Hinings, 1996; Hirsch \& Lounsbury, 1997; Oliver, 1991, 1992). Specifically, the "paradox of embedded agency" (Holm, 1995; Seo \& Creed, 2002), the question of how actors become motivated and enabled to transform the taken-for-granted structures and norms that supposedly define them, has attracted substantial attention.

In response, institutional scholars re-focused on explaining the role of interest and agency in divergent institutional change and, following DiMaggio's (1988) early lead, subsumed their efforts under the banner of "institutional entrepreneurship." This initial framing informed subsequent research in two ways: First, it pointed to the centrality of interest, agency, and resources for explaining institutionalization as a process rather than a state (e.g. Barley \& Tolbert, 1997; Greenwood \& Hinings, 1996). Secondly, it opened institutional arguments to ideas from the co-evolving entrepreneurship literature (e.g. Aldrich \& Fiol, 1994; Aldrich \& Martinez, 2001). The core argument of the institutional entrepreneurship literature, hence, centers on the conditions and mechanisms that enable entrepreneurs actively to shape their institutional environment from within.

In contrast to earlier work which portrayed change as contingent upon an exogenous shock "smacking into stable institutional arrangements" (Clemens \& Cook, 1999: 447), this strand suggests that "new institutions arise when organized actors with sufficient resources (institutional entrepreneurs) see in them an opportunity to realize interests that they value highly" (DiMaggio, 1988: 14). This change in perspective is initially fuelled by an injection of "old" institutionalist notions of interest dissatisfaction and power into the "new" institutionalism in organizational analysis. The resultant "neo"-institutionalist lens is sensitive both to actors' conflicting interests and to their embeddedness in broader social structures that assess their appropriateness and control the resources to pursue them (Greenwood \& Hinings, 1996; Hirsch \& Lounsbury, 1997). In this sense, 
organizations are seen as "infused with value" (Selznick, 1957: 17) in two ways: Their structures reflect collective notions of appropriateness, but also constitute vehicles for realizing individual interests.

In the institutional entrepreneurship literature, however, the pursuit of self-interest is not contained within organizational boundaries. Instead, when conceptualized as a positional system in which actors compete for various forms of capital (Bourdieu, 1993; Bourdieu \& Wacquant, 1992), rather than a pure network of actors, the organizational field becomes the arena-and its institutional arrangement the focus - of competition between self-interested entrepreneurs. As "the constitutive rules of any system . . . create positions allocating authoritative decision making to incumbents of some positions and duties to obey to incumbents of others" (Stryker, 2000: 179-80), motivation to (re-)shape such rule systems through institutional entrepreneurship is inherent to any organizational field. This topographical understanding of fields has led institutional scholars to focus on the field position of potential entrepreneurs (e.g. Battilana, 2006; Greenwood \& Suddaby, 2006; Leblebici, Salancik, Copay, \& King, 1991) and the maturity of the field itself as indicators of likely proponents of change and their resource-mobilization strategies for implementing it. Initially, institutional entrepreneurship was associated with disadvantaged actors located in the periphery of mature fields or with emerging fields, while entrepreneurial action by central, elite participants in mature fields has been conceptualized only relatively late as "the toughest example of embedded action" (Greenwood \& Suddaby, 2006: 43). Below we elaborate on the association of field position and entrepreneurial potential, show how different empirical foci correspond to different phases of theory development, and explain how this correspondence shaped our understanding of institutional entrepreneurship in PSFs.

\section{Institutional Entrepreneurship among Peripheral Actors and Emerging Fields}

Early work on institutional entrepreneurship considers the field periphery a fertile breeding ground for institutional entrepreneurs. The common understanding is that peripheral actors are disadvantaged by the existing rule system and therefore motivated to take entrepreneurial action. Simultaneously, they are also relatively remote from central organizational networks through which institutional prescriptions are enforced and therefore less caught by prevailing institutional arrangements. By contrast, central organizations are deemed to be privileged by the institutional status quo and subject to intense scrutiny by their peers, which make them more likely to conform to strong isomorphic pressures and not act as institutional entrepreneurs. In sum, peripheral actors are more likely to become institutional entrepreneurs because they stand to gain more, while risking less (e.g. Elsbach \& Sutton, 1992; Greenwood \& Hinings, 1996; Kraatz \& Zajac, 1996; Leblebici et al., 1991; Rao, Morrill, \& Zald, 2000).

Field center and periphery are less clearly defined in emerging fields, which also attract considerable empirical attention at this stage. As institutionalists become more interested in the structuration of institutional arrangements, they also begin to focus on processes of field construction (Aldrich \& Fiol, 1994; Anand \& Peterson, 2000; Hoffman, 1999; Lawrence \& Phillips, 2004; Lounsbury, Ventresca, \& Hirsch, 2003; Russo, 2001; SahlinAndersson, 1996). Studying emerging fields helps them understand how actors socially construct a shared understanding of the environment that ties clusters of organizations 
into a "recognized area of institutional life" (DiMaggio \& Powell, 1983: 148-9). They find that, in the absence of shared rules and dominant logics, fields consolidate around a central "issue" (Hoffman, 1999) or "attention focus" (Anand \& Peterson, 2000). Whether these are industry awards (Anand \& Peterson, 2000; Anand \& Watson, 2004), child nutrition concerns (Lawrence, Hardy, \& Phillips, 2002), or environmental considerations (Hoffman, 1999; Lounsbury, 1997; Lounsbury et al., 2003), they interlock previously disparate organizations in a collective endeavor, and help them develop a shared understanding of their field.

Emerging fields are still relatively under-organized domains, characterized by weakly entrenched, relatively localized "proto-institutions" (Lawrence et al., 2002). Their constituents recognize some degree of mutual interest, but interact sporadically rather than through a structured system of social positions. Hence, actors lack clearly delineated reference groups of dominant or peer organizations whose isomorphic demands they would have to observe. This ambiguity provides considerable opportunity and motivation for institutional entrepreneurs to act strategically, shape emerging institutional arrangements or standards to their interests, and secure for themselves a central and resourceful position in the emerging field (e.g. Fligstein \& Mara-Drita, 1996; Garud, Jain, \& Kumaraswamy, 2002; Hargadon \& Douglas, 2001; Maguire, Hardy, \& Lawrence, 2004).

These choices to attend primarily to peripheral actors and emerging fields have meant that this strand of research has greatly advanced the notion of agency in institutional theory, but has done less for addressing the puzzle of embedded agency. Attention to dissatisfied actors as principal change agents is problematic insofar as they are considered relatively isolated from isomorphic pressures. Similarly, emerging fields are characterized by low institutionalization and weak isomorphic constraints on human agency. As a result, the concept of institutional entrepreneurship has predominantly been developed from cases of strong agency but weak embeddedness.

This empirical one-sidedness has been reflected in theory development as critics note that the resultant understanding of agency is overly voluntaristic, individualistic, and disembedded (e.g. Lawrence, Suddaby, \& Leca, 2009; Leca \& Naccache, 2006; Lounsbury $\&$ Crumley, 2007; Seo \& Creed, 2002). Accounts of institutional entrepreneurship have been criticized for showing processes of institutional formation rather than transformation that are driven by "active, rational opportunists ... ready to take any action for institutional change that will enhance their individual interests, unconstrained by existing institutional arrangements" (Seo \& Creed, 2002: 240). They emulate a model of planned change with institutional entrepreneurs engaging in actions that are "purposive" (Lawrence \& Suddaby, 2006), or "directed toward" (Lawrence, 1999) realizing a preferred institutional arrangement.

Disadvantaged actors may be more motivated to initiate and plan change, but they are also less equipped to make it stick. However, while the importance of mobilizing coalitions and socio-political resources has been recognized, the focus largely remained on the skills and characteristics of mobilizing actors (e.g. Fligstein \& Mara-Drita, 1996; Garud et al., 2002; Maguire et al., 2004), rather than the activities of a collective. Accounts "evoke the image of a single organization acting innovatively" (Greenwood \& Suddaby, 2006; Hargrave \& Van de Ven, 2006; Lounsbury \& Crumley, 2007) or a heroic or "hypermuscular" (Lawrence et al., 2009) activist leading a movement of less empowered 
followers, suggesting that this early research is more about entrepreneurs than entrepreneurship.

The increasing interest in emerging fields and field construction distracts institutionalists from research in mature fields, such as the established professions. With knowledgeintensive occupations such as management consulting, investment banking, engineering, or architecture aspiring to professional status, expertise-based definitions of professionalism confront professional ones (Brint, 1994) and favor resource-based over institutional perspectives on these organizations. As exemplars of knowledge-intensive organizations (Alvesson, 1995, 2001; Empson, 2001; Hansen, Nohria, \& Tierney, 1999; Morris, 2001; Starbuck, 1992, 1993), PSFs are deemed instructive cases for advancing a knowledge-based theory of the firm (Grant, 1996), and their professional staff are primarily considered as carriers of knowledge, not institutional norms. Similarly, the rise and increasing internationalization of PSFs draws attention to their management structures (e.g. Aharoni, 1993; Brock, Powell, \& Hinings, 1999; Cooper, Hinings, Greenwood, \& Brown, 1996; Greenwood \& Hinings, 1994; Maister, 1993), but not to their embeddedness in broader institutional arrangements. In this sense, even though the mid-1990s produced a plethora of research in professional firms, little of it applied the institutionalist lens.

However, to address the criticisms discussed above and take seriously the embeddedness of agency in stable institutional structures, institutional entrepreneurship research re-oriented its empirical focus and attended to instances of institutional change initiated by privileged, central actors in mature fields who so far had been assumed to be strongly embedded and unmotivated to challenge the institutional status quo.

\section{Embedded Action by Central Elites in Mature Fields}

In response to critiques that initial accounts of institutional entrepreneurship somewhat overshot the mark of incorporating agency into institutional theory and lost sight of embeddedness, later studies work towards an understanding of "institutional entrepreneurship as embedded agency" (Garud et al., 2007). These efforts produce a trend to move away from emerging fields and focus on mature fields that have traditionally been associated with organizational homogeneity, and institutional stability (DiMaggio \& Powell, 1983; Tolbert \& Zucker, 1983).

Drawing on Seo and Creed's (2002) "contradictions" framework, this line of research argues that the potential for entrepreneurship and change is inherent in most fields, because tensions between contradictory logics intensify as fields mature. Organizations at the interstices of different institutional prescriptions are more able, and often motivated, to consider different responses to institutional pressures and initiate change (e.g. Djelic \& Quack, 2003; Greenwood, Magán Díaz, Li, \& Céspedes Lorente, 2010; Jarzabkowski, Matthiesen, \& Van de Ven, 2009; Kraatz \& Block, 2008; Pache \& Santos, 2010; Reay \& Hinings, 2005). As these fissures and contradictions run across fields, and not just their periphery, even elite organizations at the field center may become motivated and enabled to initiate change (e.g. Greenwood \& Suddaby, 2006; Rao, Monin, \& Durand, 2003; Sherer \& Lee, 2002). This type of actor was previously hypothesized to feel least motivated to challenge institutional arrangements, most constrained by institutional pressures, and thus most firmly embedded, so that institutional entrepreneurship 
originating in their midst constitutes an "exemplar of embedded agency" (Greenwood \& Suddaby, 2006).

As Greenwood and Suddaby (2006) elaborate, a subjectively perceived shortfall in performance vis-à-vis competitors is sufficient to instill a sense of dissatisfaction and motivate even elite actors to exploit their awareness of alternative institutional arrangements to address their crisis. In this view, embeddedness becomes a relative rather than a binary phenomenon insofar as it influences the nature of the institutional contradictions actors experience, the institutional arrangements they can develop, and the economic or socio-political resources they can mobilize, so that "embedded" institutional entrepreneurs in mature fields combine characteristics that make them "both marginal and central" (Castel \& Friedberg, 2009).

As institutional theorists engage more closely with contradictions and the transformation of existing institutional arrangements, they broaden their focus from institutional "creation" to include entrepreneurial efforts to "disrupt" or "maintain" existing arrangements (Lawrence \& Suddaby, 2006; Lawrence et al., 2009). At the same time, attention migrates from institutional entrepreneurs to entrepreneurship, from questions of who the entrepreneurs are and where they are located to what they do and how they do it to accomplish the "institutional work" (Lawrence \& Suddaby, 2006) of (trans-)forming institutional arrangements according to their interests. Empirical research increasingly focuses on practical actions and interactions that reconstruct institutional arrangements (Jarzabkowski et al., 2009; Kellogg, 2009) or the rhetorical strategies that change agents employ to theorize and legitimize change (e.g. Greenwood, Suddaby, \& Hinings, 2002; Jones \& Livne-Tarandach, 2008; Maguire \& Hardy, 2009; Munir \& Phillips, 2005; Suddaby \& Greenwood, 2005; Weber, Heinze, \& DeSoucey, 2008; Zilber, 2006, 2007).

These studies also problematize the previously prevailing image of the "heroic" entrepreneur who single-handedly takes on institutional structures. Institutional scholars more comprehensively engage with ideas from the social movement literature and begin to describe institutional entrepreneurship as a collective endeavor, bringing together a variety of actors who coalesce around their common project, but may not follow a specific organization's lead (Hargrave \& Van de Ven, 2006; den Hond \& de Bakker, 2007; Lounsbury \& Crumley, 2007; Rao et al., 2003; Reay, Golden-Biddle, \& Germann, 2006; Wijen \& Ansari, 2007).

Searching for strong cases of embedded action that illuminate the transformation of existing rather than the creation of new institutional arrangements, empirical work in this stream of research rediscovers classic professions such as accounting, healthcare, and law as fruitful research settings, exemplifying highly institutionalized fields. The apparent stability and strength of institutional structures in professional contexts, as well as the recognized role of professionals as institutionalized and institutionalizing actors (e.g. DiMaggio \& Powell, 1983; Scott, 2008), make professional contexts an appropriate empirical setting for studying embedded motivated action. Instead of the professions per se, however, institutionalists now attend to professional service firms as elite actors in mature fields. For instance, Greenwood and colleagues publish a series of papers on the efforts of the "Big Five" global accounting firms to legitimize multi-disciplinary practice as an appropriate organizational form (Greenwood \& Suddaby, 2006; Greenwood et al., 2002; Suddaby \& Greenwood, 2005). Covaleski, Dirsmith, \& Rittenberg (2003) attend to the same set of elite organizations and their interactions with professional and regulatory 
bodies in legitimizing new work practices. Sherer and Lee (2002) choose elite US law firms to document the demise of the highly institutionalized "Cravath"-style promotion system.

What has remained surprisingly underexplored in this extreme swing from emerging to mature fields, however, is those proto-professions and proto-professional firms whose institutional projects have made some progress, but whose organizational forms, practices, and logics cannot yet be considered fully institutionalized. These arenas, which we describe as "maturing" fields, combining characteristics of emerging and mature fields, may hold particular conditions for institutional entrepreneurship. Drawing on illustrative data from the German management consulting field (Reihlen, Smets, \& Veit, 2010), we explore those conditions and the strategies that consultancies employ to manipulate the institutional ramifications of their own existence and operation.

\section{INSTITUTIONAL ENTREPRENEURSHIP IN A MATURING FIELD: THE CASE OF MANAGEMENT CONSULTING IN GERMANY}

\section{Management Consulting as a Maturing Field}

We classify the management consultancy field in Germany as a "maturing" field, as it combines both emerging and mature properties. Management knowledge constitutes the central "issue" of the consulting field. Its creation, dissemination, and application connect consulting firms with academic institutions, media companies, and client firms, and outline a collective endeavor around which they can coalesce (Engwall \& Kipping, 2002; Faust, 2002a; Suddaby \& Greenwood, 2001). Together, they form a "recognized area of institutional life" in the sense of DiMaggio and Powell's (1983: 148) field concept, namely a "fashion-setting community" that feeds on the "dramatization of newness" (Faust, 2002a).

Kipping and Armbrüster (1999) highlight that the relatively imprecise nature of the consultancy concept, the multitude of specializations, and the frequent change of products and producers complicate the definition of field boundaries. Unlike other professional business services such as law or accounting, management consulting is not a protected occupation that requires professional certification and accreditation (Armbrüster, 2006; Groß \& Kieser, 2006; Kipping \& Armbrüster, 1999). Industry associations do exist, but they play a largely supporting and representative role, contrasting greatly with the formally accredited professional associations that regulate the practice of lawyers, accountants, and physicians. Industry associations provide opportunities for training and exchange, and they help small management consultancies to build credibility and reputation (Clark, 1995; Groß \& Kieser, 2006). Hence, the isomorphic pressures commonly exerted by professional associations or the state are weak in the consultancy field (Armbrüster, 2006; Groß \& Kieser, 2006). In this sense, the management consulting field is still emerging, characterized by residual institutional ambiguity and competing ideas of appropriate consulting practice.

Simultaneously, however, the perceived status of consultancy services and the way in which field constituents interact with and perceive each other show signs of increasing 
field maturity. Although management consulting is still a relatively young industry, it has positioned itself as "the world's newest profession" (McKenna, 2006), attaining quasiprofessional status based on the knowledge intensity of its services (Brint, 1993; Groß \& Kieser, 2006; Maister, 1993). Its large growth rates during the 1990s "were being added to a mature frame, not an adolescent skeleton" (McKenna, 2006), suggesting significant progress towards fuller institutionalization.

Another indicator of field maturity is the stratification of elites and non-elites, which differ in both scale and reputation (Greenwood and Suddaby, 2006). Similar to the more traditional law (Empson, 2007a) and accounting professions (Greenwood \& Suddaby, 2006), whose highly reputable firms are collectively known as the "Magic Circle" and the "Big Five" respectively, the consulting field is clearly stratified along these dimensions, distinguishing a small group of elite organizations from their peripheral competitors in both the global and the German context. In 2006, the top ten consultancies in Germany (out of approximately 14250 incumbents) controlled a market share of 18 percent. ${ }^{1}$ With the exception of Roland Berger Strategy Consultants, a leading national player, the German consulting market is dominated by the global elite of American consulting firms such as McKinsey \& Co., Booz Allen Hamilton, and the Boston Consulting Group. Most of those firms entered the European market in the consulting boom of the "golden sixties" (Kipping, 1999) and established the significant presence they still enjoy today.

Hence, while the boundaries of the management consultancy field are relatively fuzzy, its center is very clear. The stratification of elite and non-elite organizations, combined with the fluidity of field participation, the absence of strong isomorphic pressures, and the resultant institutional ambiguity, suggests that management consulting is best described as a maturing field. Management consultancy is caught in limbo between early emergence and full structuration. This trait suggests that processes of institutionalization are ongoing, but that there is still considerable scope for entrepreneurs to shape maturing arrangements in ways that enhance their institutional capital (Lounsbury \& Glynn, 2001; Oliver, 1997).

Even more than in an emerging field, in a maturing field organizations may find particularly motivating and enabling conditions for strategic action. The lack of institutions of professionalism (Armbrüster, 2006; Groß \& Kieser, 2006) creates institutional ambiguity and therefore weaker institutional constraints. Additionally, local or global elites can use their reputations and resourcefulness to shape maturing institutional structures to their advantage. The elites' exposure to top clients and multiple industries also helps them influence institutional arrangements (Greenwood \& Suddaby, 2006) and give direction to their institutional strategies. These institutional and organizational conditions enable strategic action, while the prospect of increased competitive advantage and economic reward acts as a motivator. Given that institutional arrangements benefit the interests of their promoters, individual consultancies are motivated to promote rules and structures that enhance their institutional capital and competitive advantage (Lounsbury \& Glynn, 2001; Oliver, 1997). These specific institutional conditions suggest that the management consultancy field is a particularly rich setting in which to explore strategies for creating and sustaining institutional capital.

Drawing on generic strategies by which self-interested actors may impose institutional constraints on other field participants (Lawrence, 1999) or relax their own (Oliver, 1991), 
we analyze how consulting firms in Germany manipulate their institutional context to enhance their institutional capital (see especially Reihlen et al., 2010).

\section{Co-optation and Lobbyism}

The customization of consultancy services (Fosstenløkken, Løwendahl, \& Revang, 2003) and the role of networked reputation in acquiring client projects (Glückler \& Armbrüster, 2003) mean that personal relationships play a strong role in selling consultancy services. Marketing measures are often personalized and aimed at forming networks with decisionmakers in client organizations (Armbrüster \& Barchewitz, 2004). Thus, the consultancy field is highly susceptible to personalized institutional strategies such as co-optation and lobbyism (see Oliver, 1991). In this specific case, co-opting may take one of two forms, depending on whether a stakeholder is imported into the consultancy or a consultant exported to co-opt an external stakeholder "from within."

Because of the relationship-driven nature of their service, management consultancies focus on incorporating employees with existing personal networks into their own business. This incorporation is exercised through lateral hires, the hiring of experienced professionals from competitors (Kaiser, 2004; Ringlstetter \& Bürger, 2004). Especially when firms move into new areas of practice, experienced professionals who bring their personal networks of colleagues and clients may provide a crucial boost for business development (Malos \& Campion, 1995).

A derivative of co-optation that is specific to consultancies and other professional service firms is known as outplacement (Maister, 1993), which does not rely on integrating important institutional decision-makers into the organization, but on placing loyal employees in client organizations or regulatory agencies. For many consulting firms with an "up-or-out" tournament promotion system (Galanter \& Palay, 1991; Gilson \& Mnookin, 1989), outplacement has become an institutionalized solution to infusing the organization with new ideas, but it has "also created a network of former employees who served as ambassadors ... within other organizations that might otherwise have been wary of employing consultants" (McKenna, 2006). The prevalence of the outplacement strategy as an instrument for reinforcing consultant-client ties is illustrated by a survey of the professional backgrounds of the DAX-30 board members. ${ }^{2}$

On average, 16 percent of all DAX-30 board members have a background in management consulting. The results ranged from 0 to 50 percent; figures close to 50 percent suggest close relationships between the corporation and the consulting field and in some cases with a specific consulting firm. Notably, in the chemical or automotive industry, where a strong life science or engineering background is desirable even among top executives, only one out of 36 board members has a consulting background. Conversely, DAX-30 banks recruited one-third of their board members from among former management consultants.

Given our indicator, by far the most successful firm in outplacing former employees into client organizations is McKinsey \& Company, ${ }^{3}$ the industry leader in the German consulting market. Of all former consultants on DAX-30 executive boards, 43 percent are former members of McKinsey. More importantly, in exceptional cases such as the Deutsche Post and the Deutsche Postbank, former employees of McKinsey occupy 50 percent and 44 percent, respectively, of the top management positions. At the same time, 
McKinsey has attained an informal status as "consultancy of choice" for both companies, reducing the volume of new business that competitors have been able to acquire. In 2006, McKinsey generated an annual fee income of an estimated $€ 80$ million, accounting for approximately 13 percent of total fee income, from this relationship (Lixenfeld, 2008; Student, 2008). Although the survey of DAX-30 companies is indicative, the alumni networks of large consultancies reach much further. McKinsey's German alumni network comprises approximately 1800 managers (Reischauer, 2005), compared to about 1000 former BCG consultants (Student, 2006).

The prospect of outplacement to prestigious client firms increases the attractiveness on the graduate labor market (Reischauer, 2005; Student, 2006). It creates institutional capital in that it helps attract new talent from leading business schools and fuels the constant stream of new entrants that is needed to sustain the up-or-out promotion system. Additionally, consultants who have successfully been outplaced with clients can help their former employer secure a steady stream of new projects, based on good personal relationships and information advantages (Bresser \& Millonig, 2003; McKenna, 2006). However, the benefit of these client-consultant ties is mutual, as clients can also benefit from employing former consultants. The employees' inside knowledge of their former firm makes it possible for them to manage service delivery more effectively and to raise performance expectations (see van den Bosch, Baaij, \& Volberda, 2005). For instance, former consultants in client organizations may have maintained good personal relationships with partners in the consultancy through whom they can sanction low-performing consulting work.

Within new public management initiatives, management consultancies are increasingly seconding members to government and policy-making committees (Bill \& Falk, 2006; Faust, 1998). A prominent example in Germany is the so-called "Hartz Committee" on labor market reform, to which McKinsey and Roland Berger Strategy Consultants seconded senior members. Work on policy-making committees builds reputation, but more importantly it constitutes a deliberate attempt to demonstrate the value of consulting services for society. Similar to client outplacements, these temporary endorsements represent a form of co-optation that enhances consultants' institutional capital, creating public awareness and legitimacy for consulting work in this sector. Such a "committee first, then consulting" strategy (Manager Magazin, 2004) opens up the public sector as a new and lucrative market for consulting services. In 2004, public organizations spent about $€ 1$ billion on consulting fees, accounting for approximately 8 percent of the total German consulting market (Falk, Rehfeld, Römmele, \& Thunert, 2006).

However, these efforts to build institutional capital also had unintended consequences that reduced it. As new stakeholders surfaced, government watchdogs began to scrutinize the government use of management consultancies; journalists and academics publicly questioned its legitimacy. The increasing influence of management consultants on political decision-making is now met with great skepticism, as critics observe the emergence of a "republic of consultants" (Leif, 2006; Niejahr \& Bittner, 2004) in which political decision-makers depend increasingly on external consulting expertise. Following a resolution of the Budget Committee of the German Bundestag, the Federal Audit Office (Bundesrechnungshof) developed guidelines for government relations with, and the use of, management consultants (Bundesrechnungshof, 2006). Hence, when some elements 
of the institutional environment, but not others, are co-opted to align with organizational interests, unintended consequences for firms' institutional capital can occur.

This means that the deliberate competitive or institutional strategies of individual firms may entail both positive and negative unintended consequences that drive the developing process of institutional change. Deliberate and emergent, and competitive and institutional components of strategy influence each other through feedback loops. For instance, the deliberate outplacement of qualified consultants in client organizations solves the incentive problems of an up-or-out career system, but also creates an emerging pattern of organizational actions that may institutionalize the use of consultancies by clients. Similarly, consultants' work on policy committees generates fee income and, at the same time, creates the incidental by-product that political consulting becomes increasingly indispensable and eventually taken for granted in the public sphere.

\section{Membership}

Membership strategies specify which organizations can legitimately exercise particular functions and thus derive benefits resulting from their activity. Nevertheless, in addition to Lawrence's (1999) original conceptualization of membership strategies, we also find distinct non-membership strategies among German management consultancies.

Small and medium-sized consultancies pursue a membership strategy in Lawrence's (1999) sense, in that they organize themselves in industry associations such as the Bundesverband Deutscher Unternehmensberater(BDU) or the RKW Beratungsnetzwerk. These associations, which serve as substitutes for established professional associations with regulatory functions, signal a minimum of consultancy competence and quality to potential clients (Groß \& Kieser, 2006).

By contrast, for leading international consultancies such membership strategies are counterproductive. In the absence of a protected occupational title and formal professional accreditation, reputation serves as a proxy for quality. Hence, elite firms can use their reputation as a "membership criterion" and form a strategic group (McGee \& Thomas, 1986) of management consultancies defined by elite status(Ferguson, Deephouse, \& Ferguson, 2000). Their rigorous, strict demands serve to maintain the exclusivity of their circle and to establish a company-specific "micro-profession," which is reinforced by in-house monitoring of quasi-professional principles (McKenna, 2006). ${ }^{4}$ This legitimation-qua-reputation gives elite consultancies access to knowledge and policymaking arenas in which best practices are created, validated, or diffused (Suddaby \& Greenwood, 2001).

By steering clear of more inclusive industry associations, elite firms avoid reputational contamination and external institutional influence. In this sense, they pursue a nonmembership, or exclusivity, strategy to enhance their individual institutional capital and weaken that of their smaller competitors.

\section{Standardization}

Standardization strategies define what is to be seen as normal, for example for a particular service. In this respect, membership and standardization strategies are interdependent, since both promote and eventually institutionalize consistent standards of professional 
practice and service quality. Those consultancies that promote a standard - and which most likely already comply with it - automatically gain legitimacy advantages and enhance their institutional capital.

For instance, in an attempt to strengthen the collective reputation and legitimacy of the consulting profession, the BDU filed a request to the Ministry of Economics to protect the title Unternehmensberater (management consultant) under occupational law. According to the proposal, the title Unternehmensberater would be awarded on the basis of specific credentials, such as academic training or practical experience. But in December 1997, after debates, the proposal was rejected by the ministry (Glückler \& Armbrüster, 2003; Groß \& Kieser, 2006; Handelsblatt, 1997).

In accord with their non-membership strategy, elite consultancy firms with a strong position in their particular fields can use more subtle standardization strategies to enhance their individual, rather than the collective, institutional capital. These consultancies can raise to the status of an institution those practices, procedures, and products in which they have competitive advantages. In this context, the creation of management fashions constitutes a standardization strategy. It at least temporarily institutionalizes concepts or practices by ascribing to them a value over and above their technical merit (Lawrence, 1999). Although fashions are transitory rationality myths and only weakly institutionalized, nevertheless while they last they are regarded as standards in their respective areas for the duration of their life-cycle. Their technical merit is not evaluated strictly by goal attainment, because their application confers benefits of perceived conformity with superior norms of rationality and progress (Benders \& van Veen, 2001; Kieser, 1997; Suddaby \& Greenwood, 2001).

Consultancies as "expert theorizers" (Strang \& Meyer, 1993) occupy privileged positions in arenas where the legitimacy of competing management innovations is constructed and contested. Within these arenas, their status enhances the impact and "positive normative emulation" of their ideas (Suchman, 1995). Thus, management fashions become important standardization devices of socially constructed business solutions. A consultancy that successfully establishes its own concepts or procedures as temporary standards enhances its own institutional capital, because it develops market preferences that constrain its competitors, which are forced to adapt and subscribe to concepts or procedures in which they are at a technical disadvantage. Further, as the use of specific consulting services becomes a more standardized response to certain management problems, the standardization efforts of individual firms can build collective institutional capital for the entire industry.

\section{Influence}

Generally, the successful marketing of consultancy services depends on a positive perception of the engagement of consultants in the target industry. The strategic influence of such a fundamental attitude can endow consultancy services with normative, and eventually cognitive, legitimacy (Røvik, 2002; Suchman, 1995).

There is clear evidence that, in the past, consultancy firms have successfully influenced the value systems not only of their clients but also of society at large, so that the support services they provide to management teams and policy-makers have become taken for granted (Falk et al., 2006; Faust, 1998; McKenna, 2006; Suchman, 1995; Wimmer, 1992). 
These observations resonate strongly with Meyer and Rowan's (1977) argument that the modernization of society makes more areas of society accessible to the rules of rationality. Management consultancies have been able to use and propel this trend by reaching out to new groups of potential clients and applying their expertise to new types of problems which traditionally had not been open to their services (Ernst \& Kieser, 2002b; Rudolph, 2004).

Influencing strategies may involve other strategies of institutional manipulation, such as outplacement and secondment strategies. However, these strategies may be more wideranging, especially in areas where firms try to influence societal value systems more generally and open up new markets.

In the business sector, consulting firms can rely on their "systems of persuasion" (Alvesson, 1993) to create institutionalized myths that buffer their operations from questioning. Based on a study of self-presentations by various global management consultancies on the internet, Bäcklund and Werr (2001) conclude that management consultancies use prevalent social myths of rationality, globalization, and universality to institutionalize their services as necessary components of successful management.

To influence value systems outside their traditional management domain, consultancies can use support strategies to demonstrate their value for political decision-making. Active engagement in social and environmental issues has also become an important mission for a large number of businesses that put corporate social responsibility and corporate citizenship high on their agenda. Management consultancies can work "pro bono" to display their social responsibility, that is, deliver services for projects of social relevance free of charge (e.g. BCG, 2008; McKinsey, 2008b; Roland Berger, 2008a). However, these initiatives also provide a strong platform for more wide-ranging societal strategies.

From the institutionalist perspective, pro bono work not only builds reputation as a socially responsible organization, but more importantly also creates impressions of ubiquity that may be perceived as an indicator of acceptance and legitimacy. Pro bono work gives consultancy firms a legitimate presence in social domains that were previously not accessible to them owing to incompatible value systems. The large, elite consultancies especially have developed their status as the new "reflective elite" (Deutschmann, 1993; Faust, 2002a) or the "supra-experts" (Ernst \& Kieser, 2002a) by applying their expertise pro bono to societal problems as diverse as climate protection (McKinsey, 2007), restructuring the church (see Hardt, 2004; Neidhart, 1997), national innovation systems (BCG, 2006), and city attractiveness (Roland Berger, 2008b). These initiatives counter negative public perceptions of consultants as hyper-rational cost-cutters. They build a legitimate basis of activity for consultancies in a wide range of societal sectors and thereby develop the consultancies' individual and collective institutional capital. Consultancies' individual efforts to manage their reputation collectively drive the institutionalization of management consultancy throughout society.

However, we note that the influencing strategy should not be considered in isolation from other, superior institutional arrangements. For instance, from a historical perspective, it is clear that the influence of management consultancies in societies with traditional values of status, prestige, and authority is lower than in meritocratic societies, which stress functional values of effectiveness and efficiency (Faust, 2002b). Therefore, an important question is to what extent changes in social values can be influenced by individual institutional entrepreneurs. 


\section{Handbook of research on entrepreneurship in professional services}

\section{CONCLUSION}

Institutional entrepreneurship has become an emerging and increasingly important research area in the field of professional services. Institutionalists make important progress in understanding field-endogenous sources of institutional change. They blend new institutionalist ideas of embeddedness with "old" ideas of interest dissatisfaction (e.g. Greenwood \& Hinings, 1996; Hirsch \& Lounsbury, 1997) and find ways of explaining this motivation for change as inherent to mature institutional structures (Greenwood \& Suddaby, 2006; Seo \& Creed, 2002). However, attention to dissatisfied actors as principal change agents isolated from isomorphic pressures is problematic for addressing the paradox of embedded agency, since it appears to bypass rather than address the paradox of embedded agency. Similarly, studies of institutional change in emergent fields attend to contexts of low institutionalization and weak isomorphic constraints on human agency. As a result, concepts of endogenous change have predominantly been developed from cases of strong agency but weak embeddedness. Therefore, we have chosen management consultancies which provide an interesting setting for studying embedded institutional entrepreneurship owing to the institutional ambiguity and low pressures from "proto-institutions" (Lawrence et al., 2002) in this maturing field.

The findings of this study advance the understanding of institutional entrepreneurship in three partially interrelated ways. First, we contribute to the understanding of institutional entrepreneurship in maturing fields. We attend to the previously neglected middle ground between emerging fields in which multiple structures, practices, and logics vie for predominance and mature fields with firmly entrenched institutional structures. We discuss the particular conditions that entrepreneurially minded actors find in maturing fields and that motivate and enable action in ways that differ from those previously documented in the literature. We outline a portfolio of strategies that institutional entrepreneurs in our study employ and show how these strategies serve a dual purpose: creating individual competitive advantage and enhancing individual or collective institutional capital. This interplay of competitive and institutional strategy has previously received little attention.

Second, this study elaborates the concept of distributed agency (Quack, 2007), which becomes important when considering the field of management consultancies. There is typically no centralized control in the consulting field, since no single agency with a monopolized power position exists to dictate the behavior of other agents. The co-presence of multiple types of actors like consulting firms, media, clients, business schools, and industry associations with different levels of involvement implies that agency is distributed across actors. With multiple localized actors contributing to an institutional change, the formation of institutional strategies may be better understood as the interplay of emergent and deliberate actions. In our case, deliberate actions to create individual competitive advantage for specific consulting firms created an emergent institutional strategy that can retrospectively be identified as having enhanced the institutional capital of the entire industry. As Mintzberg (1987a, 1987b) suggests, strategies need not be deliberate, but can also emerge from incremental and distributed patterns of actions. Although these have generally been viewed as mutually exclusive opposites, Quack (2007) has found institution building to involve both practitioners' practical problem solving and firms' deliberate political interventions. 
Third, departing from the idea of distributed agency and emergent strategy, the strategic formation can be seen as a social movement in which the sum of disperse actions makes up the development of the institutional field. Traditionally, the implicit model of change has been one of planned change, in which dissatisfied actors engage in actions that are "intentional" (Hargrave \& Van de Ven, 2006: 867), "purposive" (Lawrence \& Suddaby, 2006: 217), or "directed toward" (Lawrence, 1999: 168) realizing a new institutional arrangement. This imagery of planned institutional change seems to discount not only the interference of conflicting interests by other field participants, but also earlystage experimentation in which an institutional change project takes shape. In contrast to this position, the dynamics in such an organizational field come from the collective behavior, which can be considered as a self-organizing system in which actors respond to their local environment resulting in global patterns of actions. For example, management fashions emerge from the non-orchestrated and collective action of distributed agents rather than individual endeavors, which proposes a new perspective on institutional strategy formation, opposing the idea of individual institutional entrepreneurship (Garud \& Karnøe, 2003; Hargrave \& Van de Ven, 2006; Quack, 2007; Reay et al., 2006). Thus, in this context institutional strategies are the sum of deliberate individual strategies of distributed agents through which they intend to improve their own competitive position. These emerging patterns of collective actions trigger institutional change through complex feedback loops between other organizations in the industry setting.

Avenues for future research can be found along different strands. Theoretically, institutional entrepreneurship research has to overcome individualistic approaches that portray entrepreneurship as an overly voluntaristic endeavor or develop collectivist approaches that regard entrepreneurship as a surrogate of collective meaning systems. Alternatively, a systemic approach to institutional entrepreneurship promises a metatheoretical perspective that allows integrating agency and structure and blends the microand macro-foundations of institutional entrepreneurship (Reihlen, Klaas-Wissing, \& Ringberg, 2007).

Empirically, maturing fields like management consulting are particularly interesting settings, which offer potential for further insights on organizational field formation, disruption, and reconstruction. Since institutional entrepreneurship has traditionally been investigated in emerging or mature fields, maturing organizational fields that are caught in limbo between structurally unconfined and highly embedded agents would further inform institutional theory. In empirical studies, the consulting industry can be further differentiated into strategic groups that show different behavioral patterns during processes of institution formation. The drivers for the self-organizing behavior of dispersed agents in this context also call for further research which explains the interplay among institutional agents and between agents and institutions.

\section{NOTES}

We would like to thank Elias Kaiser for his support during this research.

1. Calculations based on BDU (2007) and Lünendonk (2008).

2. The DAX-30 lists the 30 largest German companies, publicly listed at Frankfurt stock exchange. It is the equivalent to the FTSE100 in London or the Dow Jones Index in New York. Information on consulting backgrounds was gathered from publicly available executive biographies. 


\section{Handbook of research on entrepreneurship in professional services}

3. In the following we refer only to McKinsey.

4. For instance, McKinsey \& Co's firm-specific network alone, composed of 14500 active consultants and 18000 alumni (McKinsey, 2008a), has more members than the BDU representing 530 firms covering 13000 individual consultants (BDU, 2009). This network makes it possible for McKinsey to act as a one-firm micro-profession.

\section{REFERENCES}

Abrahamson, E. 1991. Managerial fads and fashions: The diffusion and refection of innovations. Academy of Management Review, 16(3): 586-612.

Aharoni, Y. (Ed.). 1993. Coalitions and Competition: The Globalization of Professional Business Services. London: Routledge.

Aldrich, H.E., \& Fiol, C.M. 1994. Fools rush in? The institutional context of industry creation. Academy of Management Review, 19(4): 645-70.

Aldrich, H.E., \& Martinez, M.A. 2001. Many are called, but few are chosen: An evolutionary perspective for the study of entrepreneurship. Entrepreneurship Theory and Practice, 25(4): 41-57.

Alvesson, M. 1993. Organizations as rhetoric: Knowledge-intensive firms and the struggle with ambiguity. Journal of Management Studies, 30(6): 997-1022.

Alvesson, M. 1995. Management of Knowledge-Intensive Companies. Berlin: Walter de Gruyter.

Alvesson, M. 2001. Knowledge work: Ambiguity, image and identity. Human Relations, 54(7): 863-86.

Anand, N., \& Peterson, R.A. 2000. When market information constitutes fields: Sensemaking of markets in the commercial music industry. Organization Science, 11(3): 270-84.

Anand, N., \& Watson, M.R. 2004. Tournament rituals in the evolution of fields: The case of the Grammy Awards. Academy of Management Journal, 47(1): 59-80.

Arlidge, J. 2009. I'm doing "God's work." Meet Mr Goldman Sachs. Sunday Times, November 8.

Armbrüster, T. 2006. The Economics and Sociology of Management Consulting. Cambridge: Cambridge University Press.

Armbrüster, T., \& Barchewitz, C. 2004. Marketing instruments of management consulting firms: An empirical study. Paper presented at the Academy of Management Conference, New Orleans, LA.

Bäcklund, J., \& Werr, A. 2001. The construction of global management consulting: A study of consultancies web presentations. SSE/EFI Working Paper Series in Business Administration 3: 1-30.

Barley, S.R., \& Tolbert, P.S. 1997. Institutionalization and structuration: Studying the links between action and institution. Organization Studies, 18(1): 93-118

Battilana, J. 2006. Agency and institutions: The enabling role of individuals' social position. Organization, 13(5): 653-76

BCG. 2006. Innovationsstandort Deutschland-quo vadis? Available at: http://www.bcg.com/publications/ files/BCG_Studie_Innovationsstandort_Deutschland_-_quo_vadis_03Jan07.pdf (accessed March 23, 2008).

BCG. 2008. Corporate citizenship. Available at: http://www.bcg.de/bcg/csr/index.jsp (accessed March 20, 2008).

BDU.2007.Facts\&FigureszumBeratermarkt2006/2007. Bonn:BundesverbandDeutscherUnternehmensberater. BDU. 2009. Der BDU, vol. 2009. Available at: http://www.bdu.de/BDU.html (accessed January 13, 2009).

Benders, J., \& Veen, K. van. 2001. What's in a fashion? Interpretative viability and management fashions. Organization, 8(1): 33-53.

Berglund, J., \& Werr, A. 2000. The invincible character of management consulting rhetoric: How one blends incommensurates while keeping them apart. Organization, 7(4): 633-55.

Bill, H., \& Falk, S. 2006. Unternehmensberatungen in der Politikberatung. In S. Falk, D. Rehfeld, A. Römmele, \& M. Thunert (Eds.), Handbuch Politikberatung: 290-99. Wiesbaden: VS Verlag für Sozialwissenschaften.

Bosch, F.A. van den, Baaij, M.G., \& Volberda, H.W. 2005. How knowledge accumulation has changed strategy consulting: Strategic options for established strategy consulting firms. Strategic Change, 14(1): 25-34.

Bourdieu, P. 1993. Sociology in Question. London: Sage.

Bourdieu, P., \& Wacquant, L.J.D. 1992. An Invitation to Reflexive Sociology. Cambridge: Polity.

Bresser, R.K.F., \& Millonig, K. 2003. Institutional capital: Competitive advantage in light of the new institutionalism in organization theory. Schmalenbach Business Review, 55(3): 220-41.

Brint, S. 1993. Eliot Freidson's contribution to the sociology of professions. Work and Occupations, 20(3): 259-78.

Brint, S. 1994. In an Age of Experts: The Changing Role of Professionals in Politics and Public Life. Princeton, NJ: Princeton University Press. 
Brock, D., Powell, M.J., \& Hinings, C.R. (Eds.). 1999. Restructuring the Professional Organization: Accounting, Health Care and Law. London: Routledge.

Bundesrechnungshof. 2006. Einsatz externer Berater in der Bundesverwaltung. Stuttgart: Kohlhammer.

Castel, P., \& Friedberg, E. 2009. Institutional change as an interactive process: The case of the modernization of the French cancer centers. Organization Science, 21(1): 311-30.

Clark, T. 1995. Managing Consultants: Consultancy as the Management of Impressions. Buckingham: Open University Press.

Clemens, E.S., \& Cook, J.M. 1999. Politics and institutionalism: Explaining durability and change. Annual Review of Sociology, 25(1): 441-66.

Cooper, D.J., Hinings, B., Greenwood, R., \& Brown, J.L. 1996. Sedimentation and transformation in organizational change: The case of Canadian law firms. Organization Studies, 17(4): 623-47.

Covaleski, M.A., Dirsmith, M.W., \& Rittenberg, L. 2003. Jurisdictional disputes over professional work: The institutionalization of the global knowledge expert. Accounting, Organizations and Society, 28(4): 323-55.

Davis, G.F. 2009. Managed by the Markets: How Finance Reshaped America. Oxford: Oxford University Press.

Deutschmann, C. 1993. Untemehmensberater-eine neue Reflexionselite? In W. Müller-Jentsch (Ed.), Profitable Ethik-effiziente Kultur: Neue Sinnstiftung durch das Management: 57-82. München: Rainer Hampp Verlag.

DiMaggio, P. 1988. Interest and agency in institutional theory. In L.G. Zucker (Ed.), Institutional Patterns and Organizations: Culture and Environment: 3-21. Cambridge, MA: Ballinger.

DiMaggio, P. 1991. Constructing an organizational field as a professional project: US art museums, 1920-1940. In W.W. Powell \& P. DiMaggio (Eds.), The New Institutionalism in Organizational Analysis: 267-92. Chicago, IL: University of Chicago Press.

DiMaggio, P.J., \& Powell, W.W. 1983. The iron cage revisited: Institutional isomorphism and collective rationality in organizational fields. American Sociological Review, 48(2): 147-60.

DiMaggio, P., \& Powell, W.W. 1991. Introduction. In W.W. Powell \& P. DiMaggio (Eds.), The New Institutionalism in Organizational Analysis: 1-38. Chicago, IL: University of Chicago Press.

Djelic, M.-L., \& Quack, S. 2003. Conclusion: Globalization as a double process of institutional change and institution building. In M.L. Djelic \& S. Quack (Eds.), Globalization and Institutions: 302-34. Cheltenham, UK and Northampton, MA, USA: Edward Elgar Publishing.

Economist. 2007. A Survey of International Banking. London: Economist.

Elsbach, K.D., \& Sutton, R.I. 1992. Acquiring organizational legitimacy through illegitimate actions: A marriage of institutional and impression management theories. Academy of Management Journal, 35(4): 699-738.

Empson, L. 2001. Introduction: Knowledge management in professional service firms. Human Relations, 54(7): $811-17$.

Empson, L. (Ed.). 2007a. Managing the Modern Law Firm: New Challenges, New Perspectives. Oxford: Oxford University Press.

Empson, L. 2007b. Professional service firms. In S.R. Clegg \& J.R. Bailey (Eds.), International Encyclopedia of Organization Studies. London: Sage.

Engwall, L., \& Kipping, M. 2002. Introduction: Management consulting as a knowledge industry. In M. Kipping \& L. Engwall (Eds.), Management Consulting: Emergence and Dynamics of a Knowledge Industry: 1-16. Oxford: Oxford University Press.

Ernst, B., \& Kieser, A. 2002a. Consultants as agents of anxiety and providers of managerial control. Academy of Management Proceedings: $\mathrm{C} 1-13$.

Ernst, B., \& Kieser, A. 2002b. Versuch, das unglaubliche Wachstum des Beratungsmarktes zu erklären. In R. Schmidt, H.-J. Gergs, \& M. Pohlmann (Eds.), Managementsoziologie: Themen, Desiderate, Perspektiven: 56-85. München: Rainer Hampp Verlag.

Falk, S., Rehfeld, D., Römmele, A., \& Thunert, M. (Eds.). 2006. Handbuch Politikberatung. Wiesbaden: VS Verlag für Sozialwissenschaften.

Faust, M. 1998. Die Selbstverständlichkeit der Unternehmensberatung. In J. Howaldt \& R. Kopp (Eds.), Sozialwissenschaftliche Organisationsberatung: 147-81. Berlin: Sigma.

Faust, M. 2002a. Consultancies as actors in knowledge arenas: Evidence from Germany. In M. Kipping \& L. Engwall (Eds.), Management Consulting: Emergence and Dynamics of a Knowledge Industry: 146-63. Oxford: Oxford University Press.

Faust, M. 2002b. Warum boomt die Managementberatung_und warum nicht zu allen Zeiten und überall? In R. Schmidt, H.-J. Gergs, \& M. Pohlmann (Eds.), Managementsoziologie: Themen, Desiderate, Perspektiven: 19-55. München: Rainer Hampp Verlag.

Ferguson, T.D., Deephouse, D.L., \& Ferguson, W.L. 2000. Do strategic groups differ in reputation? Strategic Management Journal, 21(12): 1195-1214.

Fincham, R., \& Clark, T. 2002. Introduction: The emergence of critical perspectives on consulting. In T. Clark \& R. Fincham (Eds.), Critical Consulting: New Perspectives on the Management Advice Industry: 1-20. Oxford: Blackwell. 


\section{Handbook of research on entrepreneurship in professional services}

Fligstein, N., \& Mara-Drita, I. 1996. How to make a market: Reflections on the attempt to create a single market in the European Union. American Journal of Sociology, 102(1): 1-33.

Flood, J. 2007. Lawyers as sanctifiers: The role of elite law firms in international business transactions. Indiana Journal of Global Legal Studies, 14(1): 1-33.

Fosstenløkken, S.M., Løwendahl, B.R., \& Revang, Ø. 2003. Knowledge development through client interaction: A comparative study. Organization Studies, 24(6): 859-79.

Galanter, M., \& Palay, T.M. 1991. Tournament of Lawyers: The Transformation of the Big Law Firm. Chicago, IL: University of Chicago Press.

Garud, R., Hardy, C., \& Maguire, S. 2007. Institutional entrepreneurship as embedded agency: An introduction to the special issue. Organization Studies, 28(7): 957-69.

Garud, R., Jain, S., \& Kumaraswamy, A. 2002. Institutional entrepreneurship in the sponsorship of common technological standards: The case of Sun Microsystems and Java. Academy of Management Journal, 45(1): 196-214.

Garud, R., \& Karnøe, P. 2003. Bricolage versus breakthrough: Distributed and embedded agency in technology entrepreneurship. Research Policy, 32(2): 277-300.

Gilson, R.J., \& Mnookin, R.H. 1989. Coming of age in a corporate law firm: The economics of associate career patterns. Stanford Law Review, 41(3): 567-95.

Glückler, J., \& Armbrüster, T. 2003. Bridging uncertainty in management consulting: The mechanisms of trust and networked reputation. Organization Studies, 24(2): 269-74.

Grant, R.M. 1996. Toward a knowledge-based theory of the firm. Strategic Management Journal, 17 (Winter Special Issue): 109-22.

Greenwood, R., \& Hinings, C.R. 1994. Merging professional service firms. Organization Science, 5(2): $239-57$.

Greenwood, R., \& Hinings, C.R. 1996. Understanding radical organizational change: Bringing together the old and the new institutionalism. Academy of Management Review, 21(4): 1022-54.

Greenwood, R., Magán Díaz, A., Li, S.X., \& Céspedes Lorente, J. 2010. The multiplicity of institutional logics and the heterogeneity of organizational responses. Organization Science, 21(2): 521-39.

Greenwood, R., \& Suddaby, R. 2006. Institutional entrepreneurship in mature fields: The Big Five accounting firms. Academy of Management Journal, 49(1): 27-48.

Greenwood, R., Suddaby, R., \& Hinings, C.R. 2002. Theorizing change: The role of professional associations in the transformation of institutionalized fields. Academy of Management Journal, 45(1): 58-80.

Greenwood, R., Suddaby, R., \& McDougald, M. 2006. Introduction. In R. Greenwood, R. Suddaby, \& M. McDougald (Eds.), Professional Service Firms: 1-16. Oxford: JAI Press.

Groß, C., \& Kieser, A. 2006. Consultants on the way to professionalization? Research in the Sociology of Organizations, 24: 69-100.

Handelsblatt. 1997. Unternehmensberater wollen ihren Berufsstand gesetzlich schützen: Wirtschaftsministerium prüft Vorschlag zu Beratergesetz. Handelsblatt, September 9: k02.

Hansen, M.T., Nohria, N., \& Tierney, T. 1999. What's your strategy for managing knowledge? Harvard Business Review, 77(2): 106-16.

Hardt, C. 2004. McKinsey ist schon da: Deutschlands Kirchengemeinden müssen hart sparen. Handelsblatt, October 1: 14

Hardy, C., \& Maguire, S. 2008. Institutional entrepreneurship. In R. Greenwood, C. Oliver, K. Sahlin, \& R. Suddaby (Eds.), The Sage Handbook of Organizational Institutionalism: 198-217. London: Sage.

Hargadon, A.B., \& Douglas, Y. 2001. When innovations meet institutions: Edison and the design of the electric light. Administrative Science Quarterly, 46(3): 476-502.

Hargrave, T.J., \& Van de Ven, A.H. 2006. A collective action model of institutional innovation. Academy of Management Review, 31(4): 864-88.

Hirsch, P.M., \& Lounsbury, M. 1997. Ending the family quarrel: Toward a reconciliation of "old" and "new" institutionalisms. American Behavioral Scientist, 40(4): 406-18.

Hoffman, A.J. 1999. Institutional evolution and change: Environmentalism and the US chemical industry. Academy of Management Journal, 42(4): 351-71.

Holm, P. 1995. The dynamics of institutionalization: Transformation processes in Norwegian fisheries. Administrative Science Quarterly, 40(3): 398-422.

Hond, F. den, \& Bakker, F.G.A. de. 2007. Ideologically motivated activism: How activist groups influence corporate social change activities. Academy of Management Review, 32(3): 901-24.

Jarzabkowski, P., Matthiesen, J., \& Van de Ven, A.H. 2009. Doing which work? A practice approach to institutional pluralism. In T.B. Lawrence, R. Suddaby, \& B. Leca (Eds.), Institutional Work: Actors and Agency in Institutional Studies of Organizations: 284-316. Cambridge: Cambridge University Press.

Jones, C., \& Livne-Tarandach, R. 2008. Designing a frame: Rhetorical strategies of architects. Journal of Organizational Behavior, 29(8): 1075-99.

Kaiser, S. 2004. Humanressourcen-Management in Professional Service Firms. In M. Ringlstetter, B. Bürger, \& S. Kaiser (Eds.), Strategien und Management für Professional Service Firms: 163-83. Weinheim: Wiley. 
Kellogg, K.C. 2009. Operating room: Relational spaces and microinstitutional change in surgery. American Journal of Sociology, 115(3): 657-711.

Kieser, A. 1997. Rhetoric and myth in management fashion. Organization, 4(1): 49-74.

Kipping, M. 1999. American management consulting companies in Western Europe, 1920 to 1990: Products, reputation, and relationships. Business History Review, 73(2): 190-220.

Kipping, M., \& Armbrüster, T. 1999. The consultancy field in Western Europe. CEMP Report No. 6, University of Reading.

Kraatz, M.S., \& Block, E. 2008. Organizational implications of institutional pluralism. In R. Greenwood, C. Oliver, K. Sahlin, \& R. Suddaby (Eds.), The Sage Handbook of Organizational Institutionalism: 243-75. London: Sage.

Kraatz, M.S., \& Zajac, E.J. 1996. Exploring the limits of the new institutionalism: The causes and consequences of illegitimate organizational change. American Sociological Review, 61(5): 812-36.

Lawrence, T.B. 1999. Institutional strategy. Journal of Management, 25(2): 161-87.

Lawrence, T.B., Hardy, C., \& Phillips, N. 2002. Institutional effects of interorganizational collaboration: The emergence of proto-institutions. Academy of Management Journal, 45(1): 281-90.

Lawrence, T.B., \& Phillips, N. 2004. From Moby Dick to Free Willy: Macro-cultural discourse and institutional entrepreneurship in emerging institutional fields. Organization, 11(5): 689-711.

Lawrence, T.B., \& Suddaby, R. 2006. Institutions and institutional work. In S. Clegg, C. Hardy, T. Lawrence, \& W. Nord (Eds.), The Sage Handbook of Organization Studies: 215-53. London: Sage.

Lawrence, T.B., Suddaby, R., \& Leca, B. 2009. Introduction: Theorizing and studying institutional work. In T. Lawrence, R. Suddaby, \& B. Leca (Eds.), Institutional Work: Actors and Agency in Institutional Studies of Organizations: 1-28. Cambridge: Cambridge University Press.

Leblebici, H., Salancik, G.R., Copay, A., \& King, T. 1991. Institutional change and the transformation of interorganizational fields: An organizational history of the US radio broadcasting industry. Administrative Science Quarterly, 36(3): 333-63.

Leca, B., \& Naccache, P. 2006. A critical realist approach to institutional entrepreneurship. Organization, 13(5): $627-51$.

Leif, T. 2006. Beraten und verkauft: McKinsey \& Co._der große Bluff der Unternehmensberater. München: Bertelsmann.

Lixenfeld, C. 2008. Das Ende der blumigen Konzepte. Handelblatt, March 30

Lounsbury, M. 1997. Exploring the institutional tool kit: The rise of recycling in the U.S. solid waste field. American Behavioral Scientist, 40(4): 465-78.

Lounsbury, M. 2002. Institutional transformation and status mobility: The professionalization of the field of finance. Academy of Management Journal, 45(1): 255-66.

Lounsbury, M. 2007. A tale of two cities: Competing logics and practice variation in the professionalizing of mutual funds. Academy of Management Journal, 50(2): 289-307.

Lounsbury, M., \& Crumley, E.T. 2007. New practice creation: An institutional perspective on innovation. Organization Studies, 28(7): 993-1012.

Lounsbury, M., \& Glynn, M.A. 2001. Cultural entrepreneurship: Stories, legitimacy, and the acquisition of resources. Strategic Management Journal, 22(6/7): 545-64.

Lounsbury, M., Ventresca, M., \& Hirsch, P. 2003. Social movements, field frames and industry emergence: A cultural-political perspective on US recycling. Socio-economic Review, 1(1): 71-104.

Lünendonk. 2008. Top 25 der Managementberatungs-Unternehmen in Deutschland 2006. Kaufbeuren: Lünendonk.

McGee, J., \& Thomas, H. 1986. Strategic groups: Theory, research and taxonomy. Strategic Management Journal, 7(2): 141-60.

McKenna, C.D. 2006. The World's Newest Profession: Management Consulting in the Twentieth Century. Cambridge: Cambridge University Press.

McKinsey. 2007. Kosten und Potenziale der Vermeidung von Treibhausgasemissionen in Deutschland: Eine Studie erstellt im Auftrag von McKinsey \& Company, Inc., erstellt im Auftrag von "BDI initiativWirtschaft und Klimaschutz." Available at: http://www.bdi-online.de/Dokumente/Umweltpolitik/ Klimastudie_BDIundMcKinsey_KostenundPotenzialederVermeidungvonTreibhausgasemiss.pdf (accessed March 23, 2008)

McKinsey. 2008a. About us. Available at: http://www.mckinsey.com/aboutus/ (accessed May 13, 2008).

McKinsey. 2008b. Raum für außergewöhnliche Ideen. Available at: http://www2.mckinsey.de/html/profil/initiativen/initiativen.asp (accessed March 20, 2008).

Maguire, S., \& Hardy, C. 2009. Discourse and deinstitutionalization: The decline of DDT. Academy of Management Journal, 52(1): 148-78.

Maguire, S., Hardy, C., \& Lawrence, T. 2004. Institutional entrepreneurship in emerging fields: HIV/AIDS treatment advocacy in Canada. Academy of Management Journal, 47(5): 657-79.

Maister, D.H. 1993. Managing the Professional Service Firm. London: Simon \& Schuster. 


\section{Handbook of research on entrepreneurship in professional services}

Malos, S.B., \& Campion, M.A. 1995. An options-based model of career mobility in professional service firms. Academy of Management Review, 20(3): 611-44.

Manager Magazin. 2004. Erst Kommission, dann Beratung. Manager Magazin, January 16.

Meyer, J.W., \& Rowan, B. 1977. Institutionalized organizations: Formal structure as myth and ceremony. American Journal of Sociology, 83(2): 340-63.

Mintzberg, H. 1987a. Crafting strategy. Harvard Business Review, 65(4): 66-83.

Mintzberg, H. 1987b. The strategy concept I: Five Ps for strategy. California Management Review, 30(1): 11-18

Montgomery, K., \& Oliver, A.L. 2007. A fresh look at how professions take shape: Dual-directed networking dynamics and social boundaries. Organization Studies, 28(5): 661-87.

Morris, T. 2001. Asserting property rights: Knowledge codification in the professional service firm. Human Relations, 54(7): 819-38.

Munir, K.A., \& Phillips, N. 2005. The birth of the "Kodak moment": Institutional entrepreneurship and the adoption of new technologies. Organization Studies, 26(11): 1665-87.

Neidhart, T. 1997. Gottvertrauen in den Markt: Geldmangel zwingt die großen Kirchen, Gläubige als Kunden zu umwerben. Die Zeit, March 14.

Niejahr, E., \& Bittner, J. 2004. Die Berater-Republik. Die Zeit, February 5.

Oliver, C. 1991. Strategic responses to institutional processes. Academy of Management Review, 16(1): 145-79.

Oliver, C. 1992. The antecedents of deinstitutionalization. Organization Studies, 13(4): 563-88.

Oliver, C. 1997. Sustainable competitive advantage: Combining institutional and resource-based views. Strategic Management Journal, 18(9): 697-713.

Pache, A., \& Santos, F. 2010. When worlds collide: The internal dynamics of organizational responses to conflicting institutional demands. Academy of Management Journal, 35(3): 455-76.

Quack, S. 2007. Legal professionals and transnational law-making: A case of distributed agency. Organization, 14(5): 643-66.

Rao, H., Monin, P., \& Durand, R. 2003. Institutional change in Toque Ville: Nouvelle cuisine as an identity movement in French gastronomy. American Journal of Sociology, 108(4): 795-843.

Rao, H., Morrill, C., \& Zald, M.N. 2000. Power plays: How social movements and collective action create new organizational forms. Research in Organizational Behavior, 22: 237-83.

Reay, T., Golden-Biddle, K., \& Germann, K. 2006. Legitimizing a new role: Small wins and microprocesses of change. Academy of Management Journal, 49(5): 977-98.

Reay, T., \& Hinings, C.R. 2005. The recomposition of an organizational field: Health care in Alberta. Organization Studies, 26(3): 351-84.

Reihlen, M., Klaas-Wissing, T., \& Ringberg, T. 2007. Metatheories in management studies: Reflections upon individualism, holism, and systemism.M@n@gement, 10(3): 49-69.

Reihlen, M., Smets, M., \& Veit, A. 2010. Management consultancies as institutional agents: Strategies for creating and sustaining institutional capital. Schmalenbach Business Review (SBR), 62(3): 318-40.

Reischauer, C. 2005. In bester Gesellschaft. Capital. Available at: http://www.capital.de/unternehmen/263858 html (accessed March 20, 2008).

Ringlstetter, M., \& Bürger, B. 2004. Strategische Entwicklung von Professional Service Firms: Optionen, Herausforderungen und Umsetzungsformen. In M. Ringlstetter, B. Bürger, \& S. Kaiser (Eds.), Strategien und Management für Professional Service Firms: 283-305. Weinheim: Wiley.

Roland Berger. 2008a. Corporate responsibility. Available at: http://www.capital.de/unternehmen/263858.html (accessed March 20, 2008).

Roland Berger. 2008b. Roland Berger Studie: Deutschland lebendigste Städte. FAZ.net. Available at: http:// ranking.faz.net/staedte/article.php?txtid=studie (accessed August 23, 2008).

Røvik, K.A. 2002. The secrets of the winners: Management ideas that flow. In K. Sahlin-Andersson \& L. Engwall (Eds.), The Expansion of Management Knowledge: Carriers, Flows and Sources: 113-44. Stanford, CA: Stanford University Press.

Rudolph, H. 2004. Kolonisierungsprozesse über Expertenwissen: Unternehmensberater/innen. In 32. Kongress der Deutschen Gesellschaft für Soziologie (Ed.), Vortrag auf der Veranstaltung der Sektion Wissenssoziologie und des Arbeitskreises Professionelles Handeln. Berlin.

Russo, M.V. 2001. Institutions, exchange relations, and the emergence of new fields: Regulatory policies and independent power production in America, 1978-1992. Administrative Science Quarterly, 46(1): 57-86.

Sahlin-Andersson, K. 1996. Imitating by editing success: The construction of organizational fields. In B. Czarniawska \& G. Sevon (Eds.), Translating Organizational Change: 69-90. Berlin: de Gruyter.

Scott, W.R. 1987. The adolescence of institutional theory. Administrative Science Quarterly, 32(4): 493-512.

Scott, W.R. 2008. Lords of the dance: Professionals as institutional agents. Organization Studies, 29(2): 219-38.

Selznick, P. 1957. Leadership in Administration: A Sociological Interpretation. Evanston, IL: Row Peterson.

Seo, M.-G., \& Creed, W.E.D. 2002. Institutional contradictions, praxis, and institutional change: A dialectical perspective. Academy of Management Review, 27(2): 222-47. 
Sherer, P., \& Lee, K. 2002. Institutional change in large law firms: A resource dependency and institutional perspective. Academy of Management Journal, 45(1): 102-19.

Starbuck, W.H. 1992. Learning by knowledge-intensive firms. Journal of Management Studies, 29(6): 713-40.

Starbuck, W.H. 1993. Keeping a butterfly and an elephant in a house of cards: The element of exceptional success. Journal of Management Studies, 30(6): 885-921.

Strang, D., \& Meyer, J.W. 1993. Institutional conditions for diffusion. Theory and Society, 22(4): 487-511.

Stryker, R. 2000. Legitimacy processes as institutional politics: Implications for theory and research in the sociology of organizations. Research in the Sociology of Organizations, 17: 179-223.

Student, D. 2006. Unternehmensberater: Powerpoint of no return. Manager Magazin, 8: 26-37.

Student, D. 2008. McKinsey: Das Schweigegelübde des Novizen. Manager Magazin, 3: 10.

Suchman, M. 1995. Managing legitimacy: Strategic and institutional approaches. Academy of Management Review, 20(3): 571-610.

Suddaby, R., \& Greenwood, R. 2001. Colonizing knowledge: Commodification as a dynamic of jurisdictional expansion in professional service firms. Human Relations, 54(7): 933-53.

Suddaby, R., \& Greenwood, R. 2005. Rhetorical strategies of legitimacy. Administrative Science Quarterly, 50(1): 35-67.

Tolbert, P.S., \& Zucker, L.G. 1983. Institutional sources of change in the formal structure of organizations: The diffusion of civil service reform, 1880-1935. Administrative Science Quarterly, 28(1): 22-39.

Weber, K., Heinze, K.L., \& DeSoucey, M. 2008. Forage for thought: Mobilizing codes in the movement for grass-fed meat and dairy products. Administrative Science Quarterly, 53(3): 529-67.

Wijen, F., \& Ansari, S. 2007. Overcoming inaction through collective institutional entrepreneurship: Insights from regime theory. Organization Studies, 28(7): 1079-100.

Wimmer, R. 1992. Was kann Beratung leisten? Zum Interventionsrepertoire und Interventionsverständnis der systemischen Organisationsberatung. In R. Wimmer(Ed.), Organisationsberatung: Neue Wege und Konzepte: 59-111. Wiesbaden: Gabler.

Zilber, T.B. 2006. The work of the symbolic in institutional processes: Translation of rational myths in Israeli high tech. Academy of Management Journal, 49(2): 281.

Zilber, T.B. 2007. Stories and the discursive dynamics of institutional entrepreneurship: The case of Israeli high tech after the bubble. Organization Studies, 28(7): 1035.

Zucker, L.G. 1977. The role of institutionalization in cultural persistence. American Sociological Review, 42(5): $726-43$.

Zucker, L.G. 1983. Organizations as institutions. In S.B. Bacharach (Ed.), Research in the Sociology of Organizations: 1-47. Greenwich, CT: JAI Press. 